\title{
Morphological Image of Fresh and Cryopreserved Dog Semen Evaluted by the Strict Analysis of Sperm Morphology Method, Using Sperm Quality Analyzer (SQA IIc) Evaluation
}

\author{
P. PǨINOSILOVÁ ${ }^{1}$, A. VINKLER ${ }^{2}$, Z. VĚŽNÍK ${ }^{1}$ \\ ${ }^{1}$ Veterinary Research Institute, Brno, Czech Republic \\ ${ }^{2}$ University of Veterinary and Pharmaceutical Sciences, Brno, Czech Republic \\ Received October 4, 2005 \\ Accepted April 13, 2006
}

\begin{abstract}
Přinosilová P., A. Vinkler, Z. Věžník: Morphological Image of Fresh and Cryopreserved Dog Semen Evaluated by the Strict Analysis of Sperm Morphology Method, Using Sperm Quality Analyzer (SQA IIc) Evaluation. Acta Vet Brno 75, 2006: 393-401.

Thirty fresh ejaculates from 15 dogs were cryopreserved in Tris-fructose-citric acid-egg-yolk extender with a glycerol content of $6 \%$. Semen samples were examined by the methods of routine sperm analysis and by the SQA IIc device. The routine semen examination focused on the evaluation of parameters determining the quality of sperm membranes. The significance of monitoring semen quality in the course of the short-term survival test for predicting dog semen quality after thawing was assessed. Relevance of the assessment of sperm morphology, and above all the percentage of sperm with membrane changes in the acrosomal region was documented. The fact that the SQA device analyses semen quality by evaluating the mass of moving cells was confirmed. The results provided by the SQA IIc device appear insufficient for the needs of deeper dog semen analysis, especially morphology assessment.
\end{abstract}

Dog, sperm analysis, morphological assessment, Sperm Quality Analyser (SQA)

The testicles of breeding males are marked by their high cell production, accompanied by the natural production of insufficiently high-quality cells. A series of factors in the internal and external environment influence the production of this cell population. The proportion of abnormal cells in semen is linked to its fertilisation capacity. Morphological abnormalities of sperm in different animal species have been evaluated in connection with declines in fertility by a number of authors (Hancock 1959; Held et al. 1991; Oettlé 1993). The limit values for the occurrence of morphologically abnormal sperm in semen have been established according to convention in different species of livestock, or in the human being, and are variable. Johnston et al. (2001) and Stockner and Bardwick (1991) set the percentage of morphologically abnormal sperm in normal dog ejaculate at below $20 \%$. Threlfall (2003) considers acceptable a semen sample containing more than $70 \%$ morphologically normal sperm. Věžník et al. (2003) agreed with this value, with the proviso that primary defects in the ejaculate should not exceed $10 \%$. According to Oettlé (1993) the fertility of fresh dog semen is markedly reduced when the percentage of morphologically abnormal cells in the semen is higher than $40 \%$. For semen samples with a morphologically abnormal sperm below $40 \%$ the author obtained a pregnancy rate of $61 \%$; when morphological defects exceeded $40 \%$, this rate fell to $13 \%$. Cryopreservation intervention reduces dog ejaculate quality and thus also the fertilisation success rate (Johnston et al. 2001). Feldman and Nelson (1987) consider fresh dog semen containing more than $70 \%$ of normal sperm and less than $20 \%$ of sperm with primary defects suitable for cryopreservation.

It is essential for the AI doses that donor semen quality is good because fertility of frozen dog semen, in additon to other factors, is associated with the quality of the fresh ejaculate

Address for correspondence:

MVDr. Petra Přinosilová

Veterinary Research Institute

Hudcova 70, 621 32, Brno

Czech Rupublic
Phone: +420 533331434

Fax: +420541211229

E-mail: prinosilova@vri.cz

http://www.vfu.cz/acta-vet/actavet.htm 
after collection (Peňa et al. 1999). Nevertheless, the quality of sperm of some dogs declines more after cryopreservation than sperm of other dogs. This may be caused by variations in the quality of cell membranes (Eilts 2005). Due to the fact that resistance of dog spermatozoa to the process of cryopreservation is low (Tsutsui et al. 2000) it is important to monitor the integrity of the sperm plasma membrane when performing resistance tests in fresh semen. Acrosomal membranes are pre-programmed for membrane fusion. Accordingly, they are the most labile of all sperm membranes (Graham 2001). Changes in the character of membrane swelling and loosening or loss of acrosome are evaluated during the assessment of morphological characteristics of sperm acrosomal membrane integrity. Foote (1975) views morphological assessment of acrosomal integrity as the most reliable method for prediction of semen fertility.

The morphological examination of semen constitutes one of the most objective methods of assessment and great attention has been devoted to it in a number of studies (Bartlett 1962; Check et al. 1992; Oettlé 1993; Menkveld and Kruger 1995; Root Kustritz et al. 1998; Kuster et al. 2004). The first description of dog sperm was published by Leeuwenhoek in 1679 (Oettlé 1993). One of the first to characterise and classify morphologically abnormal sperm was Lagerlöf (1936). This classic form of evaluation was also used with small variations by Bretschneider (1948), Bonadona (1956) and a number of others. Some studies place most importance on establishing the time, species and site of noxious substance on the characteristics of changes (Menger and Menger 1981). The development of the so-called strict morphological analyses (Kru ger et al. 1986; Menkveld and Kruger 1995) allowed expanded and more accurate morphological diagnosis. For classification, the entire spermatozoon is taken into account and emphasis is placed on the multiparametric examination of spermatozoa, i.e. all changes present in the spermatozoon are evaluated. Any deviations from normal shape and structure are considered abnormal. Relating abnormalities to individual parts of the spermatozoon and dividing them into primary (developmental, major) and secondary (obtained, minor) enables us to better orientate ourselves in determining the place and time of the emergence of the abnormalities. This separation was noted while developing the computer programme SASMO (Strict Analysis of Sperm Morphology, Věžník et al. 2001).

The SQA IIc was developed for human semen analysis. The device assesses the quality of semen by creating the SMI (sperm motility index) parameter. Parameters of the device designated as sperm concentration, percentage of motile spermatozoa and percentage of sperm with normal morphology are derived by the device from SMI values on the basis of a conversion by means of specific algorithms (Comodo et al. 1997). The relationship between dog sperm motility and concentration and the SMI values has been studied by some authors (Iguer-Ouada and Verstegen 2001), but the relationship between percentages of morphologically aberrant sperm relative to the SMI values has not yet been investigated.

The aim of our research was to show the importance of morphological examination, focusing on establishing the secondary sperm abnormalities characterised as damage to the acrosome. We tested the hypothesis that it is important to monitor the parameters of dog sperm analysis in the course of the short-term survival test in order to predict semen quality after thawing.

We have also verified the possibility of using the SQA IIc device for detailed dog semen analysis. Most importantly, usability of the SQA IIc device for the assessment of dog semen morphology was investigated.

\section{Materials and Methods}

The animals and the methodology for collecting semen

Fifteen dogs of different ages from 2 to 11 years (average age 5) were included in the experiment, from the following breeds: Afghan Hound, Basset, Beagle, Doberman, Yorkshire Terrier, Labrador, German Shepherd, 
Rottweiler, Leonberger, Shetland Sheepdog and Irish Wolfhound. The dogs were owned by private keepers who brought them to the Clinic of diseases of dogs and cats for experimental semen collection and examination. The semen was collected repeatedly by manual manipulation into plastic test-tubes with a funnel, without presence of a bitch. Clenching the collector in the palm sufficed to minimize the thermal shock. The second sperm rich fraction of each semen sample was collected. In total, 30 fresh semen samples were included for examination.

Examining the semen

After collection, the sperm concentration, percentage of motile and live sperm and the morphological image were established. The concentration was examined haemocytometrically in a Bürker Chamber, the motility was examined using the counting method in a microscope under $200-400 \times$ magnification. A drop of semen was placed on a microscope slide and covered with a cover-slip, at $35^{\circ} \mathrm{C}$. Eosin-nigrosin stain was used for distinguishing live from dead sperm. The morphological assessment was carried out by monitoring the samples stained according to Karras (Gamčík et al. 1976). The samples were examined under an optical microscope at magnification $1000 \times$ using oil immersion, and were evaluated using the multiparametric method of evaluation with the SASMO (Strict Analysis of Sperm Morphology) programme (Věžník et al. 2001). The evaluation concentrated on the percentage of morphologically abnormal sperm, the percentage of sperm with primary defects, the percentage of secondary acrosomal defects and the percentage of secondary defects of tail.

The parameters of the SQA IIc device (SQA IIc, Medical Electronic Systems LTD, San Diego, CA, USA) were set as follows: SMI (sperm motility index), sperm motility, sperm concentration and normospermia. The last three indicators have been named "WHO parameters" by the device manufacturer, because they are listed in the WHO manual as criteria for the qualitative assessment of semen (WHO 1999).

The functional, morphological and SQA parameters were also established after the conclusion of the $120 \mathrm{~min}$ survival test. The test was carried out at laboratory temperature $\left(22^{\circ} \mathrm{C}\right)$ in semen diluted with physiological saline buffered with phosphate at a $\mathrm{pH}$ of 7.2. This $\mathrm{pH}$ was selected because of its activating effect on sperm motility. The ejaculates were diluted at a concentration of $100 \times 10^{6} \mathrm{spermatozoa} / \mathrm{ml}$. After $120 \mathrm{~min}$, the semen samples were heated to $35^{\circ} \mathrm{C}$ and then evaluated.

Long-term cryopreservation and thawing of semen

Individual ejaculates were centrifuged at $500 \mathrm{~g}$ for $10 \mathrm{~min}$; semen plasma was separated and then frozen and stored at $-18{ }^{\circ} \mathrm{C}$. The semen was diluted with Tris-fructose-citric acid-egg-yolk extender (modified according to Andersen 1975) with a glycerol content of $6 \%$ at a final concentration of $250-750 \times 10^{6} \mathrm{spermatozoa} / \mathrm{ml}$. The diluted semen was poured into $0.5 \mathrm{ml}$ labelled straws and the ends were sealed with polyvinylalcohol. The straws were equilibrated at $4{ }^{\circ} \mathrm{C}$ for $2 \mathrm{~h}$ and then frozen in liquid nitrogen steam in a metal straw-holder frozen to $-100{ }^{\circ} \mathrm{C}$. After $10 \mathrm{~min}$ they were stored in liquid nitrogen.

After thawing in a water bath at a temperature of $65^{\circ} \mathrm{C}$ for $6 \mathrm{~s}$, the semen samples were diluted to an approximate concentration of $100 \times 10^{6}$ spermatozoa/ml in physiological saline buffered with phosphate to a pH of 7.2 at $35^{\circ} \mathrm{C}$, and containing $20 \%$ autologous semen plasma. The parameters of sperm analysis described above were again established.

The quality evaluation of fresh ejaculates was performed by comparing the obtained values with the conventional limits of currently accepted criteria for fresh dog ejaculate quality (Věžník et al. 2000). These authors suggest that the values of evaluated parameters should not decrease by more than $10 \%$ from those of fresh semen during the short-time survival test. The parameters of semen samples after thawing were compared with the limit values of thawed dog semen samples based on the results of Linde-Forsberg and Forsberg (1989).

The relationships of the semen quality parameters were evaluated by statistically assessing changes during the survival test and during cryopreservation. Changes in the parameter values of sperm analysis during cryopreservation were established as a percentage of the increase or decline in values after thawing compared with the initial values of the fresh semen after collection. Similarly, the changes in values during the survival test were established by comparing the values obtained after $120 \mathrm{~min}$ with the initial values after collection. The parameter values for routine sperm analysis were statistically compared with the parameters of the SQA IIc device.

Statistical methods

Statistical analysis was performed using the Stat Plus software (Stat Plus, version 1.01, 1991, VRI Brno). The Pearson Correlation test was used for evaluation of correlations for parametric data. The Spearman test was used for evaluation of correlations for non-parametric data. Data were evaluated for differences between groups using the Paired t-test for parametric data and Wilcoxon Signed Rank Test for non-parametric data. The level of significance was set at $p<0.05$. The Kruskal-Wallis Test was used for analysis of variances.

\section{Results}

Tables 1 and 2 show the average values for the parameters monitored of fresh and thawed semen.

The lower limits of the qualitative criteria and the proportion of ejaculates corresponding to the conventional values in the given indicators are shown in Table 3. Table 4 shows comparison of the values of assessed parameters with the limit values that determine the quality of thawed dog semen. 

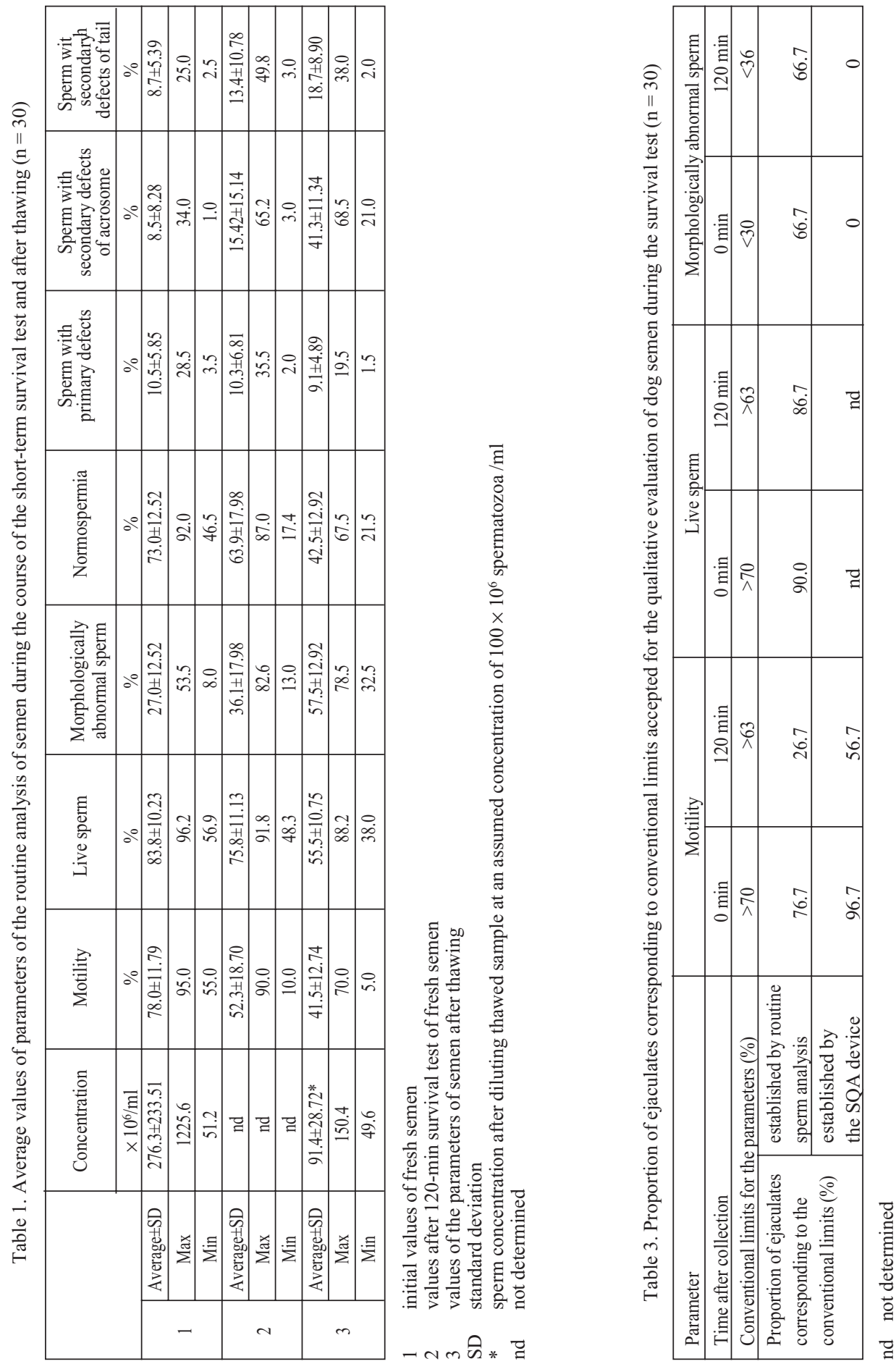
The relationship between the values of examined parameters obtained during cryopreservation and the values obtained during the survival test was investigated. A highly significant correlation was found between the decline in the live sperm percentage during the survival test of fresh semen and the decline of this parameter values during cryopreservation $(r=0.519, p<0.01)$.

There was a statistically non-significant correlation between the increase of secondary acrosomal defects during the survival test of fresh semen and the increase of these changes during cryopreservation. However, regression analysis showed an obvious positive trend. A statistically significant negative correlation $(r=-0.441, p<0.05)$ was found between the percentages of sperm with acrosomes showing membrane changes after the 120 min survival test and percentages of live sperm after thawing. Different levels of disturbed membrane integrity in the area of the acrosome as assessed by the viability test using eosin-nigrosin stain are shown in Fig. 1, 2 and 3 (see Plate II and III).

Table 2. Average values of SQA parameters of semen monitored in the course of the short-term survival test and after thawing $(\mathrm{n}=30)$

\begin{tabular}{|c|c|c|c|c|c|}
\hline \multicolumn{2}{|c|}{} & Concentration & Motility & Normospermia & SMI \\
\cline { 3 - 6 } \multicolumn{2}{c|}{} & $\times 10^{6} / \mathrm{ml}$ & $\%$ & $\%$ & $\%$ \\
\hline \multirow{3}{*}{1} & Average \pm SD & $203.1 \pm 24.24$ & $84.7 \pm 6.10$ & $53.5 \pm 3.05$ & $520.1 \pm 62.91$ \\
\cline { 2 - 6 } & Max & 225.0 & 91.0 & 57.0 & 582.0 \\
\cline { 2 - 6 } & Min & 107.0 & 62.0 & 43.0 & 293.0 \\
\hline \multirow{3}{*}{2} & Average \pm SD & nd & $64.3 \pm 19.20$ & $42.5 \pm 11.46$ & $334.8 \pm 153.20$ \\
\cline { 2 - 6 } & Max & nd & 89.0 & 56.0 & 564.0 \\
\cline { 2 - 6 } & Min & nd & 17.0 & 17.0 & 45.0 \\
\hline \multirow{3}{*}{3} & Average \pm SD & $97.2 \pm 49.93 *$ & $54.7 \pm 18.06$ & $36.6 \pm 11.85$ & $253.3 \pm 119.74$ \\
\cline { 2 - 6 } & Max & 183.0 & 79.0 & 51.0 & 458.0 \\
\cline { 2 - 6 } & Min & 0.0 & 0.0 & 0.0 & 26.0 \\
\hline
\end{tabular}

1 initial value of fresh semen

2 value after 120-minute survival test of fresh semen

3 value of the parameters of semen after thawing

SD standard deviation

SMI sperm motility index

* $\quad$ sperm concentration after diluting thawed sample at an assumed concentration of $100 \times 10^{6}$ spermatozoa $/ \mathrm{ml}$ nd not determined

Table 4. Proportion of semen samples corresponding to the limits selected by our laboratory for the use in dog semen after thawing $(\mathrm{n}=30)$

\begin{tabular}{|c|c|c|c|c|}
\hline \multicolumn{2}{|l|}{ Parameter } & Motility & Live sperm & $\begin{array}{l}\text { Morphologically } \\
\text { abnormal sperm }\end{array}$ \\
\hline \multicolumn{2}{|c|}{ Chosen limits for the parameters $(\%)$} & $>40$ & $>40$ & $>60$ \\
\hline \multirow{2}{*}{$\begin{array}{l}\text { Proportion of ejaculates } \\
\text { corresponding to the } \\
\text { limits }(\%)\end{array}$} & $\begin{array}{l}\text { established by routine } \\
\text { sperm analysis }\end{array}$ & 73.3 & 96.7 & 60.0 \\
\hline & $\begin{array}{l}\text { established by } \\
\text { SQA device }\end{array}$ & 80.0 & nd & 53.3 \\
\hline
\end{tabular}

nd not determined

The relationship between the decline of fresh sperm motility during the survival test and the decline of this parameter values during cryopreservation, and the relationship between the increase of morphologically abnormal sperm during the survival test and their increase during cryopreservation was statistically non-significant. 
Table 5. Correlations between the values of routine analysis of semen and of the SQA device and the statistical significance of the differences in the averages of these values $(\mathrm{n}=30)$

\begin{tabular}{|c|c|c|c|c|c|}
\hline \multicolumn{2}{|c|}{} & $\begin{array}{c}\text { Motility vs. } \\
\text { motility (SQA). }\end{array}$ & $\begin{array}{c}\text { Concentration vs } \\
\text { concentration (SQA) }\end{array}$ & $\begin{array}{c}\text { Normospermia vs. } \\
\text { normospermia (SQA) }\end{array}$ & $\begin{array}{c}\text { Morphologically } \\
\text { abnormal sperm vs. SMI }\end{array}$ \\
\hline \multirow{2}{*}{1} & $r$ & $0.239^{\mathrm{b}}$ & $0.570^{\mathrm{a}}$ & $0.260^{\mathrm{b}}$ & $-0.261^{\mathrm{b}}$ \\
\cline { 2 - 6 } & t-test & $\mathrm{a}$ & $\mathrm{b}$ & $\mathrm{a}$ & $\mathrm{nd}$ \\
\hline \multirow{2}{*}{2} & $r$ & $0.792^{\mathrm{a}}$ & $\mathrm{nd}$ & $0.241^{\mathrm{b}}$ & $-0.223^{\mathrm{b}}$ \\
\cline { 2 - 6 } & t-test & $\mathrm{a}$ & $\mathrm{nd}$ & $\mathrm{a}$ & $\mathrm{nd}^{\mathrm{b}}$ \\
\hline \multirow{2}{*}{3} & $r$ & $0.666^{\mathrm{a}}$ & $0.215^{\mathrm{b}}$ & $0.098^{\mathrm{b}}$ & $-0.072^{\mathrm{b}}$ \\
\cline { 2 - 6 } & t-test & $\mathrm{a}$ & $\mathrm{b}$ & $\mathrm{b}$ & $\mathrm{nd}$ \\
\hline
\end{tabular}

1 initial value of fresh semen

2 value after 120-minute survival test

3 value after thawing

SMI sperm motility index

a statistical significance where $p<0.01$

b statistically nosignificant

nd not determined

$r \quad$ correlation coefficient

Analysis of variance between the values of sperm with primary defects after collection and the values after the 120 min survival test and after thawing was carried out in order to verify the diagnostic relevance of morphological examination. Statistical non-significance of variances demonstrated concordance in these findings.

The statistically significant correlation between the increase in the percentages of morphologically abnormal sperm and sperm with secondary acrosomal defects during the survival test $(r=0.508, p<0.01)$ and also during cryopreservation $(r=0.843, p<0.01)$ was detected.

The correlations between values of determined parameters established by routine sperm analysis and the SQA device and the differences between the groups are shown in Table 5. Regression analysis of the relationship between routinely determined sperm concentrations and those determined by the SQA device showed a logarithmic character of correlation at the initial value.

\section{Discussion}

The integrity and normal resistance of the plasma membrane of sperm is a necessary prerequisite of successful fertilization, as only sperm with intact plasma membranes are capable of fertilization (Peňa et al. 1999). The importance of the sperm membrane quality assessment during the survival test for the prediction of semen quality after thawing has been documented by statistical evaluation of the results. This is consistent with the results obtained by Věžník et al. (1986) who confirmed that the increase in secondary alterations in bull sperm during the 120 min survival test significantly correlated with sperm quality after thawing (freezability).

The assessment of the percentage of sperm with secondary changes reveals sperm with disturbed membrane integrity in the area of the acrosome, but perhaps not so substantially disturbed that it manifests during the viability test with the eosin-nigrosin stain. On the other hand, a number of sperm shown by intravital dye to be dead need not have a microscopically disturbed membrane in the area of the acrosome, and therefore both parameters of investigation are important. Different levels of disturbed membrane integrity in the area of the acrosome assessed by the viability test with eosin-nigrosin stain are shown in Fig. 1, 2 and 3. Sperm with moderately disturbed membrane integrity in the area of the 
acrosome may even be motile, as long as they are not also damaged in the tail area. Nevertheless from the point of view of their future success in the fertilisation process, such sperm are not promising because their life is limited. This conclusion corresponds to Oettlé's (1986) assertion concerning the inadvisability of evaluating semen quality solely on the basis of motility itself, because motile sperm need not always be fertile.

The higher occurrence of the secondary acrosomal defects may be partly due to methods employing the morphological dyes. Stains emphasising the structures of the acrosome reveal more damaged cells than overall methods of staining. As R oot Kustritz et al. (1998) and Root and J o h n s t o n (1994) state, methods of staining and the preparation technique also have an influence on the results of the morphological assessment. Any staining method causes the occurrence of artefacts and may mask genuine defects. It is more difficult to assess stained samples of thawed semen than samples of fresh semen because elements of the extender, like egg-yolk or milk, may interfere with most stains (Oettlé 1986).

The results of our evaluation demonstrate the dependence of the increase in the proportion of morphologically abnormal sperm during storage or cryopreservation predominantly on the growth of secondary acrosomal changes, which corresponds to the assertion of Věžník et al. (2005). The lower percentage of ejaculates corresponding to the established limits for percentage of sperm with morphological defects in fresh and thawed samples (Table 3,4) demonstrated the relevance of sperm morphology assessment in addition to the parameters of motility and percentage of live sperm. It follows from the present results that morphology of live or even motile spermatozoa may be abnormal.

The statistical non-significance of the correlation between the values of the decline in motility during the survival test and during cryopreservation is caused by the high drop in sperm motility during the 120 min survival test. This marked sperm motility decrease may be the result of using a physiological saline buffered to a $\mathrm{pH}$ of 7.2 as a dilution medium. This $\mathrm{pH}$, chosen to activate sperm motility, may be less suitable for certain ejaculates because of its high alkalinity, which by supporting higher movement activity results in faster exhaustion. It is possible to explain the non-significance of the correlation between the increase of morphologically abnormal sperm during cryopreservation and the increase of these changes during the short-term survival test by the differential occurrence of secondary changes to the tail after collection, during the 120 min survival test and after thawing. The highest occurrence and also increase in secondarily changed tails in comparison with the values after collection was found in semen after thawing.

The SQA device analyses semen quality by evaluating the mass of moving cells i.e. it assesses a semen sample on the basis of two parameters: motility and concentration. By evaluation of the results obtained by the SQA, the relationships between concentration and motility of spermatozoa were demonstrated. In cases of marked differences between concentration and motility, distorted SMI values were found. For this reason, a mutual correlation between the motility values established by the classic counting method and using the SQA in the whole set of ejaculates at the initial value after collection was not attained. After eliminating semen samples with extreme differences between concentration (higher than $200 \times 10^{6}$ spermatozoa/ml) and motility (lower than 70\%), a correction of the relations occurred and the motility values established by the SQA correlated with the motility established by counting ( $r=0.679 ; p<0.01 ; \mathrm{n}=20)$. Also, the differences in means were statistically non-significant. Regression analysis of the initial concentration values established routinely and by the SQA device showed a logarithmic character of the relationship. This is influenced by the maximum concentration values that can be evaluated by SQA. The maximum possible concentration given by the device was $225 \times 10^{6}$ spermatozoa/ml. Iguer-Ouada and Verstegen (2001) did not observe 
a statistically significant correlation over the tested $200 \times 10^{6}$ cells $/ \mathrm{ml}$, possibly because of a saturation of the system.

A semen sample with very low sperm motility is given a low SMI index by the device, but sets zeroes for the so-called WHO parameters. The results recalculated from SMI using the device algorithms and designated as sperm motility and normospermia have been modulated according to the limit values. Therefore, the percentage of motility established by the SQA device ranged from zero to $91 \%$. The quantity of normal cells is set from zero to $57 \%$, given the maximum SMI value is obtained. These restricted values of normospermia assessed by SQA device caused that the obtained ejaculates were not of acceptable quality according to the mentioned conventional quality limits (Table 3).

\section{Conclusion}

The hypothesis that it is important to monitor the parameters of sperm analysis during the survival test in order to predict semen quality after thawing was tested.

The relevance of evaluation of sperm morphology, especially the percentage of sperm with membrane changes in the acrosomal area, was documented.

While using the SQA IIc device for evaluating the quality of dog semen samples, it was confirmed that the SQA device analyses ejaculate quality by evaluating the mass of moving cells. The results provided by the SQA IIc device appear insufficient for the needs of deeper dog semen analysis, especially morphology assessment.

\section{Morfologický obraz nativního a konzervovaného semene psa a jeho hodnocení metodou Striktní analýzy morfologie spermií, s využitím hodnocení přístrojem Sperm Quality Analyzer (SQA IIc)}

30 nativních ejakulátů od 15 psů bylo konzervováno Tris-fruktoso-citrát-žloutkovým ředidlem s obsahem glycerolu $6 \%$. Semeno bylo vyšetřeno metodami rutinní spermatoanalýzy a přístrojem SQA IIc. Rutinní vyšetření semene bylo zaměřeno na hodnocení parametrů určující kvalitu membrán spermie.

Byl ověřen význam sledování parametrů spermatoanalýzy v průběhu krátkodobého testu přežitelnosti pro predikci kvality semene psa po rozmrazení. Byla doložena významnost posouzení morfologického obrazu semene, a to především zastoupení spermií s membránovými změnami v oblasti akrosomu. Byla potvrzena skutečnost, že přístroj SQA analyzuje kvalitu ejakulátu na základě zhodnocení masy pohybujících se buněk. Pro potřeby hlubší spermatologické diagnostiky semene psa, zvláště pak zaměřené na morfologickou analýzu semene, se jeví výsledky poskytnuté přístrojem SQA IIc jako nedostačující.

\section{Acknowledgement}

This work was supported by associated resources for research work: The Fund for University Development Project No. 1271/2001, VZ MSM 6215712403 and the Ministry of Agriculture Project No. 0002716201.

\section{References}

ANDERSEN K 1975: Insemination with frozen dog semen based on a new insemination technique. Zuchthygiene 10: 1

BARTLETT DJ 1962: Studies on dog semen. I. Morphological characteristics. J Reprod Fertil 3: 173-189

BONADONA T 1956: Di una particolare formazione alla testa dei nemaspermi bovini mesa in evidenze al microscopia elettronico. Riv Biol 47: 297

BRETSCHNEIDER LH, VAN ITERSON W 1948: Het electronenmicroscopisch Onderzoek van het Spermium van de Stier. Tijdschr Dierg 73: 233

CHECK JH, ADELSON HG, SCHUBERT BR, BOLLENDORF A 1992: Evaluation of sperm morphology using Kruger's strict criteria. Arch Androl 28: 15-17 
COMODO F, INAUDI P, PETRILLI S, D’ANTONA N 1997: Sperm quality analyzer (SQA): A reliable tool for semen parameters evaluation. In: Proc. $10^{\text {th }}$ World Congress for In Vitro Fertilization and Assisted Reproduction. Vancouver, Canada, $24 \mathrm{p}$.

EILTS BE 2005: Theoretical aspects of canine semen cryopreservation. Theriogenology 64: 692-697

FELDMAN EC, NELSON RW 1987: Infertility of the bitch and associated breeding disorders. In: FELDMAN EC, NELSON RW: Canine and Feline Endocrinology and Reproduction. W.B. Saunders, Philadelphia, pp. 454-480.

FOOTE RH 1975: Semen quality from the bull to the freezer: an assessment. Theriogenology 3: 219-234

GAMČÍK P, KOZUMPLÍK J, SCHWARC F, VLČEK Z, ZIBRÍN M 1976: Artificial insemination and andrology in livestock (in Czech). Príroda, Bratislava. 574 p.

GRAHAM JK 2001: Assessment of Sperm Quality. AAEP Proceedings 47: 302-305

HANCOCK JL 1959: The morphologic characteristics of spermatozoa and fertility. Int J Fertil 4: 347-359

HELD JP, PRATER P, STETTLER M 1991: Spermatozoal head defect as a cause of infertility in a stallion. J Am Vet Med Assoc 199: 1760-1761

IGUER-OUADA M, VERSTEGEN JP 2001: Validation of the sperm quality analyzer (SQA) for dog sperm analysis. Theriogenology 55: 1143-1158

JOHNSTON SD, ROOT KUSTRITZ MV, OLSON PNS 2001: Semen Collection, Evaluation, and Preservation. In: JOHNSTON SD, ROOT KUSTRITZ MV, OLSON PNS: Canine and Feline Theriogenology. W.B. Saunders, Philadelphia, pp. 287-306.

KRUGER TF, MENKVELD R, STANDER FSH, LOMBARD CJ, VAN DER MERVE JP, VAN ZYL JA, SMITH K 1986: Sperm morphologic features as a prognostic factor in vitro fertilization. Fertil Steril 46: 1118-1123

KUSTER CE, SINGER RS, ALTHOUSE GC 2004: Determining sample size for the morphological assessment of sperm. Theriogenology 61: 691-703

LAGERLÖF, N. 1936: Sterility of bulls. Vet Rec 12: 121-129.

LINDE-FORSBERG C, FORSBERG M 1989: Fertility in dogs in relation to semen quality and the time and site of insemination with fresh and frozen semen. J Reprod Fertil 39 (Suppl): 299-310

MENGER H, MENGER S 1981: Comparative light and electron microscopic studies of spermiogenesis in the male rabbit, boar and ram. Arch Exp Vet Med 35: 359-74

MENKVELD R, KRUGER TF 1995: Advantages of strict (Tygerberg) criteria for evaluation of sperm morphology. Int J Androl 2: 36-42

OETTLÉ EE 1986: Changes in acrosome morphology during cooling and freezing of dog semen. Anim Reprod Sci 12: 145-150

OETTLÉ EE 1993: Sperm morphology and fertility in the dog. J Reprod Fertil 47 (Suppl): 257-260

PEŇA A, JOHANNISSON A, LINDE-FORSBERG C 1999: Post-thaw evaluation of dog spermatozoa using new triple fluorescent staining and flow cytometry. Theriogenology 52: 965-980

ROOT MV, JOHNSTON SD 1994: Basics for a Complete Reproductive Examination of the Male dog. Semin Vet Med Surg (Small Animal) 9: 41-45

ROOT KUSTRITZ MV, OLSON PN, JOHNSTON SD, ROOT TK 1998: The Effects of Stains and Investigators on Assessment of Morphology of Canine Spermatozoa. J Am Anim Hosp Assoc 34: 348- 352

STOCKNER PK, BARDWICK C 1991: The Relationship of Semen Parameters to Fertility in the Dog. Canine Pract 6: 15-23

THRELFALL WR 2003: Semen Collection and Evaluation. In: ROOT KUSTRITZ MV: Small Animal Theriogenology. Butterworth Heinemann, Missouri, pp. 97-123.

TSUTSUI T, HASE M, HORI T, ITO T, KAWAKAMI E 2000: Effects of Orvus ES Paste on canine spermatozoal longevity after freezing and thawing. J Vet Med Sci 62: 533-535

VĚŽNÍK Z, ŠVECOVÁ D, LÁNÍKOVÁ A, JURMANOVÁ K, VOJTÍŠEK B 1986: Hygienic aspects of fungal and other contaminations of the bull semen. Annual report of the phase P 06-329-809-01-04 (in Czech). Veterinary Research Institute, Brno, 63 p.

VĚŽNÍK Z et al. 2000: Evaluation of semen for assisted reproduction and selection of breeding males - Strict analysis of sperm morphology SASMO (in Czech). Veterinary Research Institute, Brno, 105 p.

VĚŽNIIK Z, MATOUŠKOVÁ O, ŠVECOVÁ D, ZAJÍCOVÁ A 2001: The use of the computer technology for the evaluation of the strict morphological sperm analysis. Vet Med-Czech 46: 35-40

VĚŽNÍK Z, ŠVECOVÁ D, ZAJÍCOVÁ A, PŘINOSILOVÁ P 2003: Functional evaluation of dog ejaculates with a priority aspect of acrosome integrity. Vet Med-Czech 48: 221-228

VĚZZNÍK Z et al 2005: Continuing professional education in spermatology and andrology and methods of sperm analysis (in Czech). Veterinary Research Institute, Brno, 197 p.

WORLD HEALTH ORGANIZATION 1999: WHO laboratory manual for the examination of human semen and sperm-cervical mucus interaction. $4^{\text {th }}$ ed. The Press Syndicate of the University of Cambridge, Cambridge, 128 p. 
Plate II

Přinosilová P. et al.: Morphological Image ... pp. 393-402

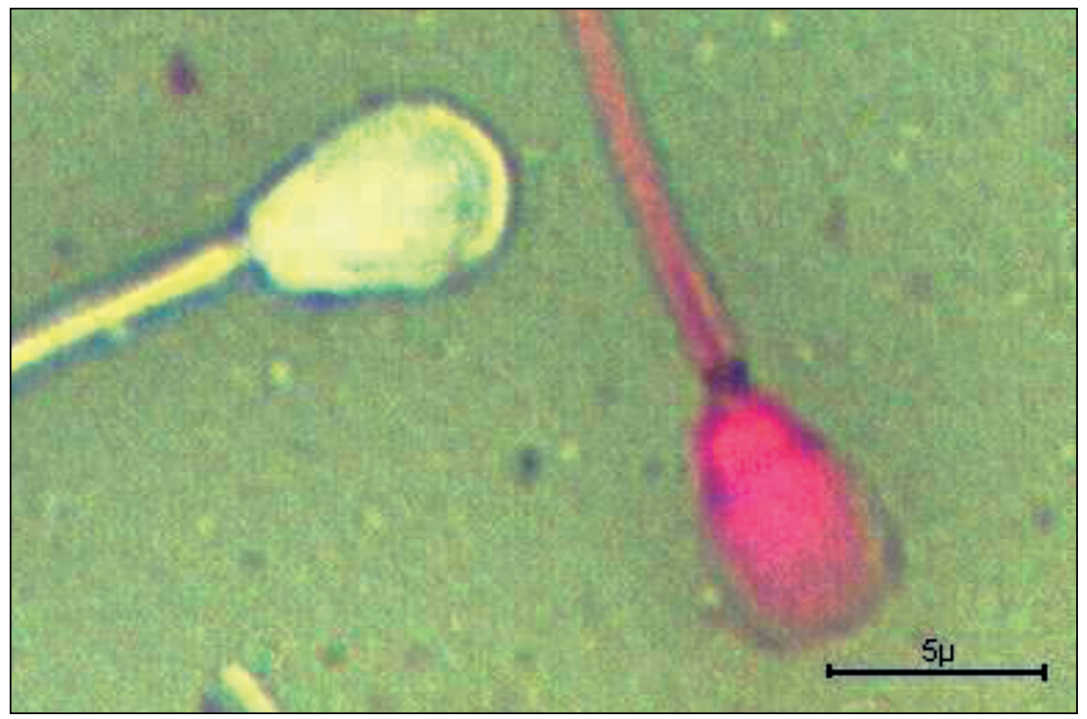

Fig. 1. Vital (white) spermatozoon with intact acrosome and dead (red) spermatozoon with swollen acrosome (eosin-nigrosin staining). Magnification $\times 1000$.

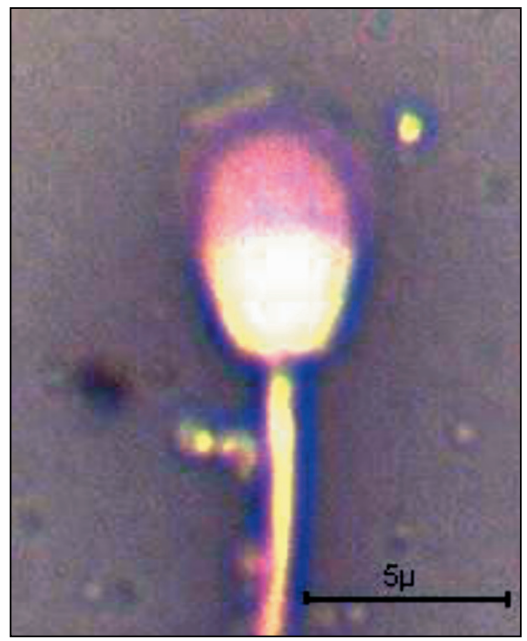

Fig. 2. Progressive penetration of the eosin stain in the cell across the impaired membrane in the area of acrosome (pink acrosomal cap; eosinnigrosin staining). Magnification $\times 1000$.

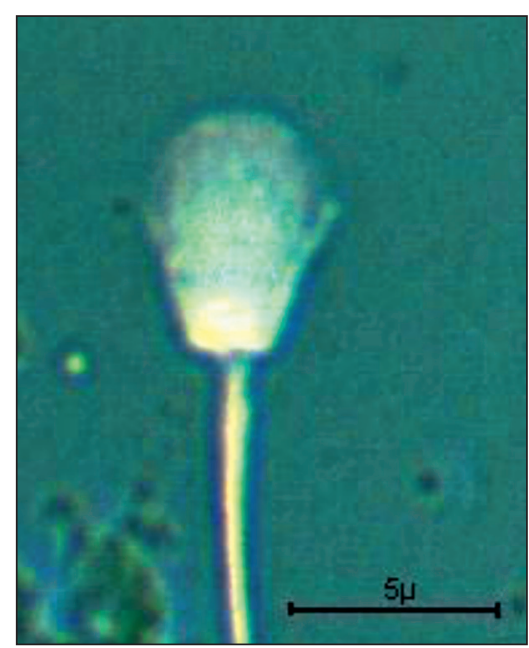

Fig. 3. Vital (white) spermatozoon with the impaired membrane in the area of acrosome morphologically expressed as swollen acrosome (eosin-nigrosin staining). Magnification $\times 1000$. 